\title{
EFEKTIVITAS PELAYANAN ADMINISTRASI TERPADU KECAMATAN DI KECAMATAN NGAMPRAH KABUPATEN BANDUNG BARAT
}

\author{
Anisa Fitri Amalia1) \\ 1)Jurusan Ilmu Pemerintahan, Fakultas Ilmu Sosial dan Ilmu Politik Universitas \\ Jenderal Achmad Yani
}

\begin{abstract}
Abstrak
Judul penelitian ini adalah "Efektivitas Pelayanan Administrasi Terpadu Kecamatan di Kecamatan Ngamprah Kabupaten Bandung Barat". Masalah dalam penelitian ini belum optimalnya pelaksanaan Pelayanan Administrasi Terpadu Kecamatan yang menyebabkan pelaksanaan pelayanan tersebut kurang maksimal. Metode penelitian yang peneliti gunakan adalah metode penelitian bersifat deskriptif dengan pendekatan kualitatif. Teknik penentuan informan yang digunakan adalah teknik purposive sampling. Hasil penelitian menunjukkan bahwa pelaksanaan Pelayanan Administrasi Terpadu Kecamatan masih belum optimal, hal ini terlihat dari: (1) ketidaktepatan waktu pelayananan, (2) jumlah sumber daya manusia yang belum memadai, (3) ketidaksesuaian mekanisme pelayanan dalam pelayanan perijinan, (4) kurangnya ketersediaan dan pemeliharaan sarana dan prasarana, (5) kurangnya sosialisasi dan pemberian informasi oleh Pemerintah Kecamatan Ngamprah, (6) belum maksimalnya peran serta masyarakat dalam memberikan evaluasi.
\end{abstract}

Kata kunci: Efektivitas, Pelayanan Administrasi Terpadu Kecamatan

\begin{abstract}
The title of this research is "The Effectiveness of Integrated District Administration Services in Ngamprah District, West Bandung Regency". The problem in this research is that the implementation of Integrated District Administration Services is not optimal which causes the implementation of these services to be less than optimal. The research method that researchers use is descriptive research methods with a qualitative approach. The technique of determining the informants used was purposive sampling technique. The results showed that the implementation of Integrated District Administration Services was still not optimal, this can be seen from: (1) inaccurate service time, (2) inadequate number of human resources, (3) mismatch of service mechanisms in licensing services, (4) lack of availability and maintenance of facilities and infrastructure, (5) lack of socialization and provision of information by the Ngamprah District Government, (6) the community's participation in providing evaluation is not maximal.
\end{abstract}

Keywords: Effectiveness, District Integrated Administration Services

\section{PENDAHULUAN}

Dalam rangka mewujudkan tatanan penyelenggaraan pemerintahan sesuai dengan tuntutan keadaan, maka berbagai kebijakan strategi telah ditetapkan, diantaranya dengan ditetapkannya Undang-undang Nomor 23 
Tahun 2014 tentang Pemerintahan Daerah. Undang-undang tersebut merupakan implementasi dari penyelenggaraan pemerintah daerah yang mengatur dan mengurus rumah tangganya sendiri dengan tujuan untuk mempercepat terwujudnya kesejahteraan masyarakat melalui peningkatan pelayanan, pemberdayaan dan peran serta masyarakat serta peningkatan daya saing daerah dengan memperhatikan prinsip demokratis, pemerataan, keadilan, keistimewaan dan kekhususan suatu daerah.

Pelayanan publik menurut Sinambela (2010:5) adalah "pemenuhan keinginan dan kebutuhan masyarakat oleh penyelenggara Negara". Pelayanan publik erat kaitannya dengan masyarakat karena masyarakat merupakan objek yang dilayani oleh pelaksana pelayanan publik yaitu pemerintah. Pelayanan publik merupakan salah satu tugas penting yang tidak dapat diabaikan oleh Pemerintah Daerah sebab jika komponen pelayanan terjadi stagnasi maka hampir dipastikan semua sektor akan terhambat.

Masalah yang muncul dalam pelayanan mencerminkan bahwa belum efektifnya pelayanan yang diselenggarakan guna memenuhi kebutuhan hidup masyarakat dan masih belum sesuai dengan bentuk pelayanan yang ideal. Efektivitas pelayanan publik adalah satu kondisi tercapainya tujuan pelayanan publik. Tujuan pelayanan publik pada dasarnya adalah untuk memuaskan masyarakat dan guna mencapai kepuasan itu dituntut kualitas pelayanan yang prima yang tercermin dari asas-asas penyelenggaraan pelayanan publik berdasarkan Undang-undang Nomor 25 Tahun 2009 tentang Pelayanan Publik .

Pelayanan Administrasi Terpadu Kecamatan diselenggarakan dengan maksud untuk mewujudkan kecamatan sebagai pusat pelayanan terpadu di kabupaten/kota bagi kecamatan yang secara kondisi geografis daerah akan lebih efektif dan efisien dilayani melalui kecamatan. Kecamatan sebagai Perangkat Daerah Kabupaten/Kota mempunyai peran yang sangat strategis, karena sebagai ujung tombak pelayanan, barometer penyelenggaraan pelayanan publik dan etalase penyelenggaraan pemerintahan daerah di Kabupaten/Kota. 
Berdasarkan Peraturan Menteri Dalam Negeri Nomor 4 Tahun 2010 tentang Pelayanan Administrasi Terpadu Kecamatan (PATEN) Pasal 29 menjelaskan bahwa: "seluruh kecamatan ditetapkan sebagai penyelenggara PATEN selambat-lambatnya 5 (lima) tahun sejak ditetapkan Peraturan Menteri ini”. Maka kebijakan PATEN di Kabupaten Bandung Barat pertama kalinya disahkan pada tanggal 14 Desember 2013 di Kecamatan Ngamprah. Keterlibatan Kabupaten Bandung Barat dalam menyukseskan kebijakan yang dibuat oleh Kementerian Dalam Negeri ini adalah untuk mewujudkan sistem pemerintahan yang baik (Good Governance). Di samping itu dengan ditetapkannya Keputusan Bupati Bandung Barat Nomor 45 Tahun 2011 tentang Pelimpahan sebagian Urusan Pemerintahan kepada Camat di Lingkungan Kabupaten Bandung Barat dijadikan dasar oleh kecamatan yang ada di Kabupaten Bandung Barat untuk melaksanakan PATEN dengan sebaik-baiknya. Kemudian dengan pemberian pelimpahan kewenangan ini juga diharapkan dapat memperpendek rentang kendali dan pendelegasian wewenang di kecamatan.

Menurut Peraturan Menteri Dalam Negeri Nomor 4 Tahun 2010 tentang Pedoman Pelayanan Administrasi Terpadu Kecamatan, standar pelayanan dalam PATEN meliputi:
a. Jenis Pelayanan
b. Persyaratan Pelayanan
c. Proses/Prosedur pelayanan
d. Pejabat yang bertanggung jawab
e. Waktu Pelayanan
f. Biaya Pelayanan

Setiap jenis pelayanan memiliki standar pelayanan yang berbedabeda meliputi persyaratan pelayanan, pejabat yang bertanggung jawab, dan biaya pelayanan. Namun sama dalam segi proses/prosedur pelayanan dan waktu pelayanan. Menurut peraturan yang tercantum di Surat Keputusan Camat Ngamprah Nomor 22 Tahun 2013 tentang Penyelenggaraan Paten di Kecamatan Ngamprah. Pelayanan yang diberikan bersifat one day service (ODS) dimana proses pelayanan diselesaikan dalam waktu 1 (satu) hari, 
kecuali pelayanan yang memerlukan proses verifikasi di lapangan maksimal 4 (empat) hari.

Namun dalam beberapa jenis pelayanan lainnya masih sering ditemui permasalahan sehingga pelayanan belum berjalan dengan baik yang dibuktikan dengan belum tercapainya target pelayanan. Hal ini disebabkan oleh berbagai faktor misalnya dalam pelayanan E-KTP sering timbulnya ketidakakuratan pelayanan yang diberikan oleh aparat yaitu adanya kesalahan dalam penginputan data oleh aparat kecamatan karena pembuatan E-KTP yang begitu melonjak sehingga membuat petugas kurang teliti dalam melakukan penginputan data. Kemudian, dengan belum tercapainya target pelayanan dikarenakan tidak adanya sistem jemput bola dan kurangnya sosialisasi yang dilakukan pemerintah Kecamatan Ngamprah sehingga masih banyaknya penduduk yang belum mengurus EKTP. Selain itu masih banyak pelayanan yang tidak sesuai dengan waktu yang ditetapkan.

Dengan munculnya permasalahan dalam pelayanan maka pelayanan perlu terus dievaluasi dalam pelaksanaannya agar dapat dinilai sejauh mana pelayanan sudah berjalan sesuai dengan yang diharapkan. Bentuk evaluasi pelayanan salah satunya adalah melalui survey kepuasan masyarakat terhadap pelayanan seperti yang dilakukan oleh Kecamatan Ngamprah. Cara ini ditempuh dengan memberikan kuesioner kepada masyarakat setelah mendapatkan pelayanan yang dibutuhkan. Dalam kuesioner terdapat beberapa indikator mengenai jalannya pelayanan kemudian masyarakat dapat menilai apakah pelayanan telah sesuai dengan yang diharapkan atau belum. Peneliti akan mencantumkan tabel hasil survey kepuasan masyarakat terhadap PATEN di Kecamatan Ngamprah Tahun 2016 sebagai berikut.

Tabel 1.1

Hasil Survey Kepuasan Masyarakat terhadap Pelayanan Administrasi Terpadu Kecamatan di Kecamatan Ngamprah Tahun 2016

\begin{tabular}{|c|l|c|c|}
\hline No. & Jenis Pelayanan & Nilai & Kategori \\
\hline 1. & $\begin{array}{l}\text { Kesesuaian persyaratan } \\
\text { dengan hasil/jenis pelayanan }\end{array}$ & 2,43 & $\begin{array}{c}\text { Kurang } \\
\text { baik }\end{array}$ \\
\hline
\end{tabular}




\begin{tabular}{|c|c|c|c|}
\hline & yang diberikan & & \\
\hline & $\begin{array}{l}\text { Prosedur Pelayanan memberikan } \\
\text { kemudahan }\end{array}$ & 2,53 & Baik \\
\hline & Ketepatan waktu pelayanan & 2,28 & $\begin{array}{l}\text { Kurang } \\
\text { Baik }\end{array}$ \\
\hline 4. & Kewajaran biaya pelayanan & 2,51 & Baik \\
\hline & $\begin{array}{l}\text { Hasil dari pelayanan yang telah } \\
\text { diberikan }\end{array}$ & 2,40 & $\begin{array}{c}\text { Kurang } \\
\text { Baik }\end{array}$ \\
\hline & $\begin{array}{l}\text { Kemampuan petugas dalam } \\
\text { memberikan pelayanan }\end{array}$ & 3,06 & Baik \\
\hline & $\begin{array}{l}\text { Kesopanan dan keramahan } \\
\text { petugas }\end{array}$ & 2,48 & $\begin{array}{l}\text { Kurang } \\
\text { Baik }\end{array}$ \\
\hline & $\begin{array}{l}\text { Pelaksanaan maklumat/janji } \\
\text { layanan yang telah dijanjikan oleh } \\
\text { penyelenggara pelayanan }\end{array}$ & 2,53 & Baik \\
\hline & $\begin{array}{l}\text { Tindak lanjut pengaduan yang } \\
\text { dilaksanakan oleh unit pelayanan }\end{array}$ & 3,20 & Baik \\
\hline
\end{tabular}

Pelayanan Administrasi Terpadu Kecamatan di Kecamatan Ngamprah masih mengalami beberapa masalah diantaranya:

a. Masih terdapat pelayanan yang prosesnya tidak sesuai dengan waktu yang telah ditentukan. Hal ini dapat dibuktikan dengan peraturan yang tercantum di Surat Keputusan Camat Ngamprah Nomor 22 Tahun 2013 tentang Penyelenggaraan PATEN di Kecamatan Ngamprah. Pelayanan yang diberikan seharusnya bersifat one day service (ODS) dimana proses pelayanan diselesaikan dalam waktu 1 (satu) hari, kecuali pelayanan yang memerlukan proses verifikasi di lapangan maksimal 4 (empat) hari. Namun dalam kenyataannya beberapa pelayanan dapat mencapai lebih dari 4 (empat) hari.

b. Sering terjadinya ketidakakuratan pelayanan yang diberikan oleh aparat kecamatan sehingga menyebabkan adanya kesalahan-kesalahan dalam penginputan data karena melonjaknya permohonan terhadap pelayanan.

c. Masih sering terjadinya pelaksanaan pelayanan yang tidak sesuai dengan alur atau prosedur PATEN yaitu dalam pelayanan perijinan. Hal ini terjadi karena petugas loket (front line officer) kurang memahami pelayanan perijinan.

d. Kurangnya sosialisasi yang diberikan oleh aparat kecamatan terkait dengan pelayanan. Hal ini dibuktikan dengan masih seringnya masyarakat yang datang tidak membawa persyaratan yang seharusnya karena kurangnya 
sosialisasi dan pemberian informasi oleh aparat kecamatan. Di samping itu, tidak adanya banner, pamflet, maupun informasi online yang dapat diakses masyarakat terkait dengan pelayanan.

Berdasarkan masalah-masalah yang ditemukan dalam Pelayanan Administrasi Terpadu Kecamatan di Kecamatan Ngamprah maka peneliti tertarik untuk melakukan penelitian lebih dalam terkait "Efektivitas Pelayanan Administrasi Terpadu Kecamatan di Kecamatan Ngamprah Kabupaten Bandung Barat”.

\section{TINJAUAN PUSTAKA}

\section{Pengertian Efektivitas}

Efektivitas menurut Siagian (2001:24) "Efektivitas adalah pemanfaatan sumber daya, sarana, dan prasarana dalam jumlah tertentu yang secara sadar ditetapkan sebelumnya untuk menghasilkan sejumlah barang atas jasa kegiatan yang dijalankannya”. Jadi efektivitas menunjukan keberhasilan dari segi tercapai tidaknya sasaran yang telah ditetapkan, jika hasil kegiatan semakin mendekati sasaran berarti makin tinggi efektivitasnya.

Konsep efektivitas yang dikemukakan oleh para ahli organisasi dan manajemen memiliki makna yang berbeda, tergantung pada acuan yang dipergunakan. Stoner menekankan (dalam Tangkilisan 2005:138) bahwa: "pentingnya efektivitas organisasi dalam pencapaian tujuan-tujuan organisasi dan efektivitas adalah kunci dari kesuksesan suatu organisasi”. Sedangkan Miller (dalam Tangkilisan 2005:138) mengemukakan bahwa: "efektivitas dimaksud sebagai tingkat seberapa jauh suatu sistem sosial mencapai tujuannya".

Efektivitas harus dibedakan dengan efisiensi. Efisiensi mengandung pengertian perbandingan antara biaya dan hasil, sedangkan efektivitas secara langsung dihubungkan dengan pencapaian suatu tujuan. Selanjutnya dikatakan oleh Georgopualos dan Tannebaum (dalam Tangkilisan 2005:139) bahwa: "efektivitas organisasi adalah tingkat sejauh mana suatu organisasi yang merupakan sistem sosial dengan segala sumber daya dan sarana tertentu yang tersedia memenuhi tujuan- 
tujuannya tanpa pemborosan dan menghindari ketegangan yang tidak perlu diantara anggota-anggotanya". Jadi secara umum ada pandangan bahwa efektivitas dimaksudkan atau dapat didefinisikan dalam batas- batas tingkat pencapaian tujuan organisasi.

Upaya mengevaluasi jalannya suatu organisasi dapat dilakukan melalui konsep efektivitas. Konsep ini adalah salah satu faktor untuk menentukan apakah perlu dilakukan perubahan secara signifikan terhadap bentuk, atau manajemen organisasi. Dalam hal ini efektivitas merupakan pencapaian tujuan organisasi melalui pemanfaatan sumber daya yang dimiliki secara efisien, ditinjau dari sisi masukan (input) maupun keluaran (output). Suatu kegiatan dikatakan efisien apabila dikerjakan dengan benar dan sesuai dengan prosedur, sedangkan efektif bila kegiatan tersebut dilaksanakan dengan benar dan dapat memberikan hasil yang bermanfaat. Gibson (dalam Tangkilisan 2005:141) mengatakan bahwa efektivitas organisasi dapat pula diukur sebagai berikut:

1. Kejelasan tujuan yang hendak dicapai;

2. Kejelasan strategi pencapaian tujuan;

3. Proses analisis dan perumusan kebijaksanaan yang mantap;

4. Perencanaan yang matang;

5. Penyusunan program yang tepat;

6. Tersedianya sarana dan prasarana; dan

7. Sistem pengawasan dan pengendalian yang bersifat mendidik.

Definisi-definisi tersebut melihat efektivitas organisasi dengan menggunakan tujuan akhir atau tujuan yang diinginkan. Pada kenyataannya, dalam upaya pencapaian tujuan akhir, organisasi harus mengenali kondisi-kondisi yang dapat menghalangi tercapainya tujuan. Efektivitas merupakan suatu konsep yang dapat dipakai sebagai sarana untuk mengukur keberhasilan suatu organisasi yang dapat diwujudkan dengan memperhatikan resiko dan keadaan yang dihadapi.

\section{Pengertian Pelayan Publik}

Menurut Undang-undang Nomor 25 Tahun 2009 tentang Pelayanan Publik mendefinisikan bahwa pelayanan publik adalah "kegiatan atau 
rangkaian kegiatan dalam rangka pemenuhan kebutuhan pelayanan sesuai dengan peraturan perundang-undangan bagi setiap warga Negara dan penduduk atas barang, jasa dan/atau pelayanan administratif yang disediakan oleh penyelenggara pelayanan publik". Pelayanan adalah suatu tindakan yang dilakukan untuk memenuhi kebutuhan orang lain (konsumen, pelanggan, tamu, pasien, penumpang dan lain- lain) pada tingkat pemuasannya hanya dapat dirasakan oleh orang yang melayani dan dilayani.

Widodo (2001:6) mengemukakan bahwa: "Pelayanan publik dapat diartikan sebagai pemberian pelayanan (melayani) keperluan orang atau masyarakat yang mempunyai kepentingan pada organisasi itu sesuai dengan aturan pokok atau tata cara yang telah ditetapkan”. Menurut Kotler (dalam Sinambela 2010:4) menelaah pelayanan publik secara konseptual, dibahas pengertian kata demi kata, yaitu: "pelayanan adalah setiap kegiatan yang menguntungkan dalam suatu kumpulan atau kesatuan, dan menawarkan kepuasan meskipun hasilnya tidak terikat pada suatu produk secara fisik, sementara istilah publik berasal dari Bahasa Inggris yaitu public yang berarti umum, masyarakat, negara”. Oleh karena itu pelayanan publik diartikan sebagai setiap kegiatan yang dilakukan oleh pemerintah terhadap sejumlah manusia yang memiliki setiap kegiatan yang menguntungkan dalam suatu kumpulan atau kesatuan, dan menawarkan kepuasan meskipun hasilnya tidak terikat pada suatu produk secara fisik.

Menurut Widodo (2001:8) sebagai perwujudan dari apa yang harus diperhatikan dan dilakukan oleh pelayan publik agar kualitas layanan menjadi baik maka dalam memberikan layanan publik sebaiknya:

1. Mudah dalam pengurusan bagi yang berkepentingan (prosedurnya sederhana)

2. Mendapat pelayanan yang wajar

3. Mendapat pelayanan yang sama tanpa pilih kasih

4. Mendapat perlakuan yang jujur dan terus terang (transparan)

Dengan demikian, dapat disimpulkan bahwa pelayanan publik merupakan segala kegiatan dalam rangka pemenuhan kebutuhan dasar sesuai dengan hak-hak dasar setiap warga negara dan penduduk berupa 
suatu barang, jasa atau pelayanan administrasi, yang disediakan oleh penyelenggara pelayanan yaitu pemerintah, baik pemerintah pusat, pemerintah daerah, BUMN, dan BUMD yang terkait dengan kepentingan publik sesuai dengan aturan pokok dan tata cara yang telah ditetapkan.

\section{Konsep Pelayanan Administrasi Terpadu Kecamatan}

PATEN merupakan singkatan dari Pelayanan Administrasi Terpadu Kecamatan. Pengertian PATEN sesuai dengan Peraturan Menteri Dalam Negeri No.4 Tahun 2010 adalah "penyelenggaraan pelayanan publik di kecamatan yang proses pengelolaannya, mulai dari permohonan sampai ke tahap terbitnya dokumen dilakukan dalam satu tempat". Satu tempat di sini berarti cukup melalui satu meja atau loket pelayanan. Sistem ini memposisikan warga masyarakat hanya berhubungan dengan petugas meja/loket pelayanan di kecamatan. Ketika warga masyarakat datang untuk melakukan pengurusan pelayanan administrasi, tidak perlu lagi mendatangi setiap petugas yang berkepentingan, seperti kepala seksi, sekretaris camat dan camat. Warga cukup menyerahkan berkas ke petugas meja/loket pelayanan, duduk menunggu sejenak, kemudian dipanggil untuk menerima dokumen yang sudah selesai. Setelah itu melakukan pembayaran (bila ada tarif yang harus dibayar).

Asas PATEN, sebagai bagian dari upaya peningkatan kualitas pelayanan publik khususnya jenis pelayanan administrasi, maka PATEN menganut asas-asas pelayanan publik sesuai dengan Undang-undang Nomor25 Tahun 2009 tentang Pelayanan Publik, asas-asas itu adalah:

1. Kepentingan umum, yang berarti pemberian pelayanan oleh petugas pelaksana PATEN tidak boleh mengutamakan kepentingan pribadi atau golongan;

2. Kepastian hukum, berarti ada jaminan bagi terwujudnya hak dan kewajiban antara penerima pelayanan (waga masyarakat) dan pemberi pelayanan (aparat kecamatan) dalam penyelenggaraan PATEN;

3. Kesamaan hak, berarti pemberian pelayanan dalam PATEN tidak membedakan suku, ras, agama, golongan, gender, dan status ekonomi; 
4. Keseimbangan hak dan kewajiban, berarti pemenuhan hak itu harus sebanding dengan kewajiban yang harus dilaksanakan, baik oleh pemberi maupun penerima pelayanan;

5. Keprofesionalan, berarti setiap pelaksana PATEN harus memiliki kompetensi yang sesuai dengan bidang tugasnya; f. Partisipastif, berarti peningkatan peran serta masyarakat dalam penyelenggaraan PATEN dengan memperhatikan aspirasi, kebutuhan, dan harapan masyarakat;

6. Persamaan perlakuan/tidak diskriminatif berarti dalam penyelenggaraan PATEN, setiap warga masyarakat berhak mendapatkan pelayanan yang adil;

7. Keterbukaan berarti setiap penerima pelayanan dapat dengan mudah mengakses dan memperoleh informasi tentang PATEN;

8. Akuntabilitas, berarti proses penyelenggaraan PATEN harus dapat dipertanggungjawabkan sesuai dengan peraturan perundang-undangan;

9. Fasilitas dan perlakuan khusus bagi kelompok rentan, berarti ada pemberian kemudahan terhadap kelompok rentan sehingga tercipta keadilan dalam pelayanan;

10. Ketepatan waktu, berarti penyelesaian setiap jenis pelayanan yang dikelola dilakukan tepat waktu sesuai dengan standar pelayanan PATEN;

11. Kecepatan, kemudahan, dan keterjangkauan, berarti setiap jenis pelayanan dalam PATEN dilakukan secara cepat, mudah, dan terjangkau oleh warga masyarakat penerima pelayanan.

Pelayanan Administrasi Terpadu Kecamatan diselenggarakan dengan maksud untuk mewujudkan kecamatan sebagai pusat pelayanan masyarakat dan menjadi simpul pelayanan bagi badan/kantor Pelayanan Terpadu Satu Pintu (PTSP). Adapun tujuan diselenggarkannya PATEN adalah untuk meningkatkan kualitas pelayanan dan mendekatkan pelayanan kepada masyarakat. Pelaksanaan PATEN di Kecamatan Ngamprah dimulai pada tanggal 14 Desember 2013. Sebagai dasar penguatan pelaksanaan PATEN di Kecamatan Ngamprah kemudian tercetus Peraturan Bupati Bandung Barat Nomor 45 Tahun 2011 Tentang Pelimpahan sebagian Urusan Pemerintahan kepada Camat di Lingkungan Kabupaten Bandung Barat. 


\section{METODE PENELITIAN}

Penelitian ini dilaksanakan pada Kecamatan Ngamprah Kabupaten Bandung Barat sebagai lokasi penyelenggaraan aktivitas pemerintahan dan pelayanan publik yang dilakukan oleh aparat pemerintah yang meliputi Pelayanan Administrasi Terpadu Kecamatan diselenggarakan dengan maksud untuk mewujudkan kecamatan sebagai pusat pelayanan masyarakat. Dengan pendekatan deskriptif kualitatif dan pengambilan sampel penelitian secara purposive sampling.

\section{HASIL DAN PEMBAHASAN}

\section{Efektivitas Pelayanan Administrasi Terpadu Kecamatan di Kecamatan Ngamprah Kabupaten Bandung Barat}

Efektivitas Pelaksanaan Pelayanan Administrasi Terpadu Kecamatan di Kecamatan Ngamprah Kabupaten Bandung Barat dapat ditinjau dari makna ganda efektivitas pelayanan, yang meliputi:

1. Pelaksanaan fungsi oleh aparat pemerintah

2. Peran serta masyarakat

3. Hasil (output) mampu melaksanakan kesejahteraan

Adapun dimensi dan indikator yang digunakan peneliti sebagai tolak ukur dalam Efektivitas Pelayanan Administrasi Terpadu Kecamatan di Kecamatan Ngamprah Kabupaten Bandung Barat adalah sebagai berikut:

1. Pelaksanaan fungsi oleh aparat pemerintah, dengan indikator sebagai berikut:

a. Memberikan pelayanan sesuai dengan standar pelayanan yang berlaku

b. Menyediakan sarana dan prasarana guna menunjang pelayanan

c. Memberikan informasi dan sosialisasi terkait dengan pelayanan

2. Peran serta masyarakat, dengan indikator sebagai berikut:

Memberikan masukan dan evaluasi dalam proses penyelenggaraan pelayanan

3. Mampu melaksanakan kesejahteraan, dengan indikator sebagai berikut: Pelayanan memberikan kemudahan masyarakat terhadap pemenuhan kebutuhan hidup masyarkat 
Dalam pembahasan ini akan mendeskripsikan hasil penelitian melalui wawancara dan observasi yang peneliti lakukan dengan pegawai Kecamatan Ngamprah serta Masyarakat Kecamatan Ngamprah dan hasil analisa untuk mendapatkan gambaran jelas mengenai efektivitas Pelayanan Administrasi Terpadu Kecamatan di Kecamatan Ngamprah Kabupaten Bandung Barat dengan indikator-indikator yang telah peneliti sebutkan di atas dan indikator-indikator tersebut akan dijabarkan pada uraian berikut ini:

\section{Pelaksanaan fungsi oleh aparat pemerintah}

Peran aparat pemerintah dalam melaksanakan fungsinya dalam pelayanan merupakan hal yang sangat penting. Aparat berkewajiban dan bertanggung jawab untuk memberikan layanan yang baik dan profesional karena hal itu dipandang sebagai salah satu perwujudan dari fungsi aparatur negara sebagai abdi masyarakat di samping sebagai abdi negara. Pelaksanaan fungsi itu sendiri sudah diatur dalam sebuah peraturan yang memberikan rincian apa saja yang harus dilakukan aparat pemerintah dalam memenuhi kebutuhan masyarakat dimana masyarakat harus dianggap sebagai "raja" dan perlu "dilayani”.

Berdasarkan hasil wawancara dan hasil observasi yang dilakukan oleh peneliti, maka dapat disimpulkan bahwa jika dilihat secara keseluruhan, pelaksanaan PATEN di Kecamatan Ngamprah sudah berjalan dengan efektif hanya saja masih terdapat beberapa kekurangan atau permasalahan yaitu mekanisme atau alur pada jenis pelayanan perijinan yang sering tidak sesuai dengan alur PATEN yang sebenarnya. Melalui PATEN, aparat berupaya untuk terus meningkatkan kualitas pelayanan pada masyarakat untuk mencapai pelayanan yang prima namun dalam realisasinya dalam beberapa pelayanan masih mengalami masalah baik dari segi alur birokrasi maupun waktu penyelesaian pelayanan.

Dalam dimensi pelaksanaan fungsi oleh Pemerintah Daerah dengan indikator pemerintah memberikan pelayanan sesuai dengan standar pelayanan yang berlaku peneliti akan menyimpulkan secara lebih rinci terkait dengan ke-13 (tiga belas) pelayanan. Dalam dimensi pelaksanaan fungsi oleh Pemerintah Daerah dengan indikator pemerintah memberikan 
pelayanan Permohonan E-KTP sesuai dengan standar pelayanan yang berlaku peneliti menyimpulkan bahwa pelayanan ini berjalan kurang baik karena masih seringnya mengalami kesalahan dalam penginputan data yang menyebabkan harus dilakukannya kembali perekaman ulang sehingga hal ini membuat waktu pelayanan E-KTP semakin terulur lama.

Dimensi pelaksanaan fungsi oleh Pemerintah Daerah dengan indikator pemerintah memberikan pelayanan Permohonan Kartu Keluarga sesuai dengan standar pelayanan yang berlaku peneliti menyimpulkan bahwa sudah berjalan dengan baik karena pemerintah kecamatan sudah melaksanakan pelayanan sesuai dengan standar yang berlaku mulai dari proses pelayanan dan waktu pelayanan. Jika pelayanan Permohonan Kartu Keluarga mengalami keterlambatan waktu, hal itu bukan disebabkan oleh pemerintah kecamatan melainkan lamanya proses di Dinas Kependudukan dan Catatan Sipil.

Dimensi pelaksanaan fungsi oleh Pemerintah Daerah dengan indikator pemerintah memberikan pelayanan Permohonan Surat Pindah/datang sesuai dengan standar pelayanan yang berlaku peneliti menyimpulkan bahwa pelayanan sudah berjalan dengan baik karena pelayanan ini cenderung sederhana mulai dari proses hingga persyaratan yang perlu dipenuhi oleh masyarakat. Selain itu pemerintah pun cepat tanggap dalam menangani pelayanan ini.

Dimensi pelaksanaan fungsi oleh Pemerintah Daerah dengan indikator pemerintah memberikan pelayanan Permohonan Patwa Waris sesuai dengan standar pelayanan yang berlaku peneliti menyimpulkan bahwa pelayanan sudah berjalan dengan baik karena sama halnya dengan pelayanan Permohonan Surat Pindah/datang yang cukup sederhana dan sifatnya hanya meneruskan berkas yang sudah diproses di Desa. Kemudian pelayanan yang diberikan cepat sehingga pemohon tidak perlu menunggu lama hanya sekitar 15 menit untuk menyelesaikan pelayanan Permohonan Patwa Waris.

Dimensi pelaksanaan fungsi oleh Pemerintah Daerah dengan indikator pemerintah memberikan pelayanan Permohonan Ijin Mendirikan Bangunan sesuai dengan standar pelayanan yang berlaku peneliti 
menyimpulkan bahwa pelayanan ini kurang baik karena dalam alur pelayanan pun masih sering tidak menerapkan alur PATEN sepenuhnya dan waktu yang dibutuhkan dalam verifikasi lapangan cenderung lama karena kurangnya staff di bidang Pembangunan dan Pemeliharaan Sarana Umum.

Dimensi pelaksanaan fungsi oleh Pemerintah Daerah dengan indikator pemerintah memberikan pelayanan Permohonan atau Rekomendasi Pendirian Tower sesuai dengan standar pelayanan yang berlaku peneliti menyimpulkan bahwa pelayanan ini kurang baik karena sama halnya dengan pelayanan Permohonan Ijin Mendirikan Bangunan yaitu mekanisme atau alur dalam pelayanan yang belum sepenuhnya menerapkan alur PATEN sehingga hal ini membuat pelayanan kurang efektif karena masyarakat masih harus menghampiri ruangan kasi untuk mengurus berkasnya.

Dimensi pelaksanaan fungsi oleh Pemerintah Daerah dengan indikator pemerintah memberikan pelayanan Rekomendasi Pembangunan di Kawasan Bandung Utara sesuai dengan standar pelayanan yang berlaku peneliti menyimpulkan bahwa pelayanan ini kurang baik jika dilihat dari standar pelayanan yang berlaku yaitu dalam prosedur pelayanan yang juga dialami oleh jenis perijinan lainnya. Dalam ketepatan waktu, jenis pelayanan ini sudah cukup tepat waktu karena memang sedikitnya pemohon dalam pelayanan ini bahkan dalam data jumlah pelayanan pada tahun 2014-2016, Rekomendasi Pembangunan di Kawasan Bandung Utara hanya ada 1 (satu) pemohon yaitu pada tahun 2014 saja.

Dimensi pelaksanaan fungsi oleh Pemerintah Daerah dengan indikator pemerintah memberikan pelayanan Permohonan Ijin Gangguan (Ho) sesuai dengan standar pelayanan yang berlaku peneliti menyimpulkan bahwa pelayanan ini kurang baik karena dilihat dari alur pelayanan yang tidak menerapkan PATEN secara sepenuhnya sehingga menyebabkan masih seringnya masyarakat mengantri di Ruangan Bidang Ekonomi dan Pendapatan Potensi Daerah karena seharusnya masyarakat sudah tidak perlu mendatangi ruangan kasi yang bersangkutan dalam peraturan PATEN. 
Dimensi pelaksanaan fungsi oleh Pemerintah Daerah dengan indikator pemerintah memberikan pelayanan Permohonan Ijin Operasional Pendidikan sesuai dengan standar pelayanan yang berlaku peneliti menyimpulkan bahwa pelayanan sudah berjalan dengan baik karena sudah sesuai dengan standar yang berlaku terutama dalam alur pelayanan yang sesuai dengan mekanisme PATEN, waktu pelayanan yang dapat mencapai ODS (one day service), biaya pelayanan yang dikenakan di Bidang Pemberdayaan Masyarakat dan Desa pun gratis secara keseluruhan termasuk dengan Permohonan Ijin Operasional Pendidikan.

Dimensi pelaksanaan fungsi oleh Pemerintah Daerah dengan indikator pemerintah memberikan pelayanan Permohonan Surat Keterangan Tidak Mampu sesuai dengan standar pelayanan yang berlaku, peneliti menyimpulkan bahwa pelayanan yang diberikan oleh pemerintah kecamatan sudah baik karena cepat dalam memproses pelayanan dan juga cepat tanggap. Apabila ada berkas pemohon yang secara statusnya bekerja dan tidak memungkinkan untuk melakukan permohonan SKTM maka pihak kecamatan segera meminta keakuratan dari desa yaitu berupa kelengkapan surat keterangan bahwa pemohon telah tidak dalam posisi bekerja atau berpenghasilan dalam saat itu. Prosesnya tidak rumit dan dengan waktu sehari pun pelayanan sudah bisa selesai.

Dimensi pelaksanaan fungsi oleh Pemerintah Daerah dengan indikator pemerintah memberikan pelayanan Permohonan Kartu Tanda Pencari Kerja/kuning mampu sesuai dengan standar pelayanan yang berlaku, peneliti menyimpulkan bahwa dalam pelayanan ini sudah berjalan dengan baik karena proses pelayanan yang mudah dan sederhana dalam pemrosesan berkas sehingga pelayanan ini dapat mencapai ODS (One Day Service).

Dimensi pelaksanaan fungsi oleh Pemerintah Daerah dengan indikator pemerintah memberikan pelayanan Permohonan Surat Keterangan Domisili Haji mampu sesuai dengan standar pelayanan yang berlaku, peneliti menyimpulkan bahwa pelayanan ini sudah baik karena sama halnya dengan jenis pelayanan lain yang ditangani oleh Bidang Pemberdayaan Masyarakat dan Desa bahwa pelayanan cenderung 
sederhana karena sifatnya hanya meneruskan berkas dari desa dan dapat diselesaikan dalam satu hari kerja sehingga pemohon tidak perlu menunggu lama.

Dimensi pelaksanaan fungsi oleh Pemerintah Daerah dengan indikator pemerintah memberikan pelayanan Rekomendasi Proposal mampu sesuai dengan standar pelayanan yang berlaku, peneliti menyimpulkan bahwa pelayanan ini sudah berjalan dengan baik karena mulai dari pemrosesan berkas hingga melakukan verifikasi lapangan terkait dengan kegiatan tidak dihadapkan oleh permasalahan teknis. Kemudian tugas Kasi Pemberdayaan Masyarakat dan Desa dalam pelayanan ini hanya pemeriksaan berkas dan peninjauan lapangan saja terkait dengan kegiatan yang bersangkutan.

Dari ke-13 (tiga belas) jenis pelayanan yang terdapat di Kecamatan Ngamprah, maka dapat disimpulkan bahwa terdapat 8 (delapan) jenis pelayanan yang sudah berjalan dengan baik dan 5 (lima) jenis pelayanan yang berjalan kurang baik. Melihat mayoritas kategori pelayanan yang sudah berjalan dengan baik maka dapat disimpulkan bahwa indikator pemerintah memberikan pelayanan sesuai dengan standar pelayanan yang berlaku sudah berjalan dengan efektif hanya saja masih memiliki beberapa kekurangan dalam pelaksanaannya.

Selanjutnya aparat kecamatan belum optimal dalam menyediakan maupun memelihara sarana prasarana yang dapat menunjang kenyamanan masyarakat dan pelayanan di Kantor Kecamatan Ngamprah. Keluhan masyarakat terkait dengan sarana prasarana dalam pelaksanaan PATEN yang menjadi sangat penting adalah ketersediaan papan informasi terkait dengan persyaratan dan biaya pelayanan. Selain itu, pemeliharaan fasilitas yang belum optimal sehingga sedikit menimbulkan ketidaknyamanan masyarakat selaku pengguna pelayanan. Dengan adanya PATEN seharusnya mampu membawa "wajah" kecamatan menjadi tempat pelayanan yang lebih baik dalam melayani dan membentuk kepuasan masyarakat. 


\section{Peran Serta Masyarakat}

Pelayanan publik bertujuan untuk memenuhi kebutuhan hidup masyarakat dan dalam konteks ini masyarakat sebagai pihak yang dilayani harus dapat merasa terpenuhi dan terpuaskan dengan pelayanan yang diberikan oleh pemerintah.

Berdasakan hasil wawancara dan hasil observasi maka dapat disimpulkan bahwa fasilitas yang disediakan oleh aparat dalam pemberian evaluasi belum membuahkan sebuah keberhasilan karena adakalanya peran serta masyarakat tidak maksimal. Langkah yang perlu dilaksanakan adalah dengan meningkatkan pemahaman masyarakat itu sendiri mengenai pentingnya keterlibatan masyarakat dalam memberikan suatu masukan terkait dengan pelayanan. Maka dalam hal ini dimensi peran serta masyarakat dengan indikator memberikan masukan dalam proses penyelenggaraan pelayanan belum berjalan dengan baik.

Dalam dimensi peran serta masyarakat dengan indikator masyarakat memberikan masukan dalam proses penyelenggaraan pelayanan masih kurang baik karena dalam hal ini masyarakat masih sering bersikap acuh dalam memberikan evaluasi terkait pelayanan dan tidak serius dalam pengisian kuesioner. Namun hal ini juga didukung karena masyarakat kurang paham terhadap butir pertanyaan dalam kuesioner survey kepuasan masyarakat.

\section{Mampu melaksanakan kesejahteraan}

Tujuan keberadaan pemerintah adalah untuk mencapai kesejahteraan masyarakat, melalui penyelenggaraan pelayanan kepentingan umum (social service atau public service). Pelayanan publik bertujuan untuk memenuhi kebutuhan- kebutuhan masyarakat terutama kebutuhankebutuhan administratif masyarakat, dalam upayanya masyarakat tersebut meningkatkan kesejahteraan hidupnya.

Berdasarkan kedua hasil wawancara kepada masyarakat selaku pengguna layanan maka peneliti dapat menganalisis bahwa masyarakat telah merasakan perbedaan antara pelayanan konvensional yang diterapkan sebelum PATEN dan setelah diterapkannya PATEN. Perbedaan 
yang dirasa oleh masyarakat pun perubahan positif terutama dalam memudahkan masyarakat dalam memahami setiap langkah atau cara dalam mengurus berkas dalam pelayanan di Kecamatan Ngamprah.

Hasil observasi yang dilakukan peneliti menunjukkan bahwa dengan adanya PATEN dapat membawa perubahan yang signifikan ke arah positif sehingga adanya peningkatan kualitas pelayanan yaitu jelasnya maklumat pelayanan yang diberikan oleh aparat kecamatan kepada pemohon pelayanan. Kemudian pelayanan di Kecamatan Ngamprah dapat lebih terukur salah satunya dalam segi waktu dimana adanya batas waktu penyelesaian pelayanan yaitu ODS (One Day Service) atau 4 hari maksimal pelayanan.

Dalam hal ini dapat diketahui bahwa pelaksanaan PATEN adalah sebagai wujud nyata implementasi kewajiban dasar pemerintah untuk mewujudkan kesejahteraan masyarakatnya. Kemudahan-kemudahan yang diupayakan oleh pemerintah dalam rangka mendapatkan pelayanan secara langsung telah memberikan kemudahan pula terhadap masyarakat dalam memperoleh kebutuhan- kebutuhan hidupnya terutama dalam kebutuhan administrasi.

Dalam dimensi melaksananakan kesejahteraan masyarakat dalam indikator pelayanan memberikan kemudahan kepada masyarakat, maka indikator ini sudah efektif karena dengan diterapkannya inovasi yang semakin memudahkan masyarakat dalam mendapatkan pelayanan yaitu dengan adanya pelayanan ekstra, hanya saja masih diperlukannya sosialisasi terkait inovasi pelayanan ini. Pada dasarnya pun PATEN memang bertujuan untuk mendekatkan pelayanan kepada masyarakat karena dalam hal ini masyarakat tidak perlu mengurus perijinan berskala kecil ke Badan Penanaman Modal dan Pelayanan Perizinan Terpadu dan hal ini sudah terealisasikan di Kecamatan Ngamprah.

\section{KESIMPULAN}

Berdasarkan hasil pembahasan mengenai pelaksanaan pelayanan administrasi terpadu kecamatan di Kecamatan Ngamprah Kabupaten Bandung Barat, maka peneliti dapat mengambil kesimpulan yaitu: 
1. Pelaksanaan fungsi oleh pemerintah dalam memberikan pelayanan sesuai dengan standar pelayanan yang berlaku dinilai sudah berjalan dengan baik namun masih terdapat beberapa hal yang masih perlu diperbaiki, penyediaan dan pemeliharaan sarana dan prasarana yang belum optimal, dan pemerintah belum optimal dalam memberikan informasi dan sosialisasi terkait dengan pelayanan.

2. Dalam pelaksanaan PATEN di Kecamatan Ngamprah, pemerintah kecamatan sudah berusaha menyediakan sarana untuk menyampaikan saran dan kritik masyarakat agar terciptanya interaksi dua arah antara pemerintah dan masyarakatnya, namun pada pelaksanaannya masyarakat justru tidak tertarik dan tidak maksimal dalam memanfaatkan sarana tersebut.

3. Pelaksanaan PATEN di Kecamatan Ngamprah disimpulkan dapat mempermudah masyarakat dalam memperoleh kebutuhan hidupnya karena dengan adanya sistem PATEN, prosedur yang dilalui menjadi lebih sederhana. Kemudian dengan adanya inovasi dalam pelayanan yaitu Pelayanan Ekstra yang memberikan masyarakat lebih banyak kemudahan.

\section{SARAN}

1. Perlu dilakukannya pembinaan dan pelatihan terkait dengan PATEN untuk petugas Kecamatan Ngamprah dan juga perlu ditambahnya personil di bidang Pembangunan dan Pemeliharaan Sarana Umum.

2. Perlu adanya peningkatan dan pemeliharaan sarana dan prasarana agar lebih menunjang kelancaran PATEN di Kecamatan Ngamprah

3. Sosialisasi dan pemberian informasi terkait dengan PATEN dan segala inovasinya harus lebih gencar dilakukan agar masyarakat paham dan dapat maksimal dalam memanfaatkan pelayanan yang ada.

4. Penyediaan kotak saran yang lebih strategis dan penyusunan indikator dalam kuesioner menggunakan kalimat yang lebih mudah dipahami oleh masyarakat agar masyarakat tidak jenuh dan paham terhadap butir pertanyaan dalam survey kepuasan masyarakat. 


\section{DAFTAR PUSTAKA}

Dunn, William M. 2000. Pengantar Analisis Kebijakan Publik. Yogyakarta: Gajah Mada University Press

Kurniawan, Agung. 2005. Transformasi Pelayanan Publik.

Yogyakarta: Pembaruan

Lukman, Sampara. 2000. Manajemen Kualitas Pelayanan. Jakarta: STIA LAN Press

Moenir. 2005. Manajemen Pelayanan Umum di Indonesia. Jakarta: Bumi Aksara Moleong, Lexy J. 2007. Metodologi Penelitian Kualitatif. Bandung: PT Remaja Rosdakarya

Ndraha, Taliziduhu. 2011. Kybernology (Ilmu Pemerintahan Baru). Jakarta: Rineka Cipta

Sabarno, Hari. 2007. Memandu Otonomi Daerah Menjaga Kesatuan Bangsa. Jakarta: Sinar Grafika

Salam, Setiawan. 2007. Manajemen Pemerintahan Indonesia. Jakarta: Djambatan Siagian, Sondang P. 2001. Manajemen Sumber Daya Manusia. Jakarta: Bumi Aksara

Sinambela, Lijan Poltak. 2010. Reformasi Pelayanan Publik. Jakarta: PT Bumi Aksara

Sugiyono. 2011. Metode Penelitian Kuantitatif Kualitatif R\&D. Bandung: Alfabeta

Sumaryadi, Nyoman I. 2005. Efektivitas Implementasi Kebijakan Otonomi Daerah. Jakarta: Citra Utama

Syafiie, Inu Kencana. 2007. Pengantar Ilmu Pemerintahan. Bandung: Refika Aditama

Tangkilisan, Nogi Hessel. 2005. Manajemen Publik. Jakarta: PT. Gramedia Widiasarana Indonesia

Thamrin, Husni. 2013. Hukum Pelayanan Publik di Indonesia. Jogja: Aswaja Presindo

Widodo, Joko. 2001. Good Governance Telaah Dari Dimensi Akuntabilitas, Kontrol Birokrasi Pada Era Desentralisasi dan Otonomi Daerah. Surabaya: Insan Cendekia 